\title{
Molecular Mechanisms of Bladder Outlet Obstruction in Transgenic Male Mice Overexpressing Aromatase (Cyp19a1)
}

\author{
Wei Lin, ${ }^{*}$ Nafis A. Rahman, ${ }^{\dagger \neq \S \rrbracket ~ J i a n ~ L i n, ~},{ }^{\| * *}$ \\ Hua Zhang, ${ }^{*}$ Kemian Gou, ${ }^{*}$ Wanpeng Yu, ${ }^{*}$ \\ Dahai Zhu, ${ }^{\dagger \dagger}$ Ning Li, ${ }^{*}$ Ilpo Huhtaniemi, ${ }^{\dagger \neq \ddagger}$ and \\ Xiangdong $\mathrm{Li}^{\star}$ \\ From the State Key Laboratory for Agro-Biotechnology," Faculty \\ of Biological Sciences, China Agricultural University, Beijing, \\ China; the Department of Physiology, ${ }^{\dagger}$ University of Turku, \\ Turku, Finland; the Departments of Cell Biology, ${ }^{\ddagger}$ Molecular and \\ Human Genetics, ${ }^{\S}$ and Obstetrics and Gynecology, "Tlorida \\ International University College of Medicine, Miami, Florida; the \\ Institute of Urology," Peking University, Beijing, China; the \\ Department of Urology,** Peking University First Hospital, \\ Beijing, China; the National Laboratory of Medical Molecular \\ Biology, It Institute of Basic Medical Sciences, Chinese Academy \\ of Medical Sciences and Peking Union Medical College, Beijing, \\ China; and the Department of Reproductive Biology, \\ Hammersmith Campus, Imperial College London, London, United \\ Kingdom
}

We investigated the etiology and molecular mechanisms of bladder outlet obstruction (BOO). Transgenic (Tg) male mice overexpressing aromatase (Cyp19a1) under the ubiquitin $C$ promoter in the estrogen-susceptible C57B1/6J genetic background (AROM+/ 6J) developed inguinal hernia by 2 months and severe BOO by 9 to 10 months, with $100 \%$ penetrance. These mice gradually developed uremia, renal failure, renal retention, and finally died. The BOO bladders were threefold larger than in age-matched wild-type (WT) males and were filled with urine on necropsy. Hypotrophic smooth muscle cells formed the thin detrusor urinae muscle, and collagen III accumulation contributed to the reduced compliance of the bladder. p-AKT and $\operatorname{ER} \alpha$ expression were up-regulated and Pten expression was down-regulated in the BOO bladder urothelium. Expression of only ER $\alpha$ in the intradetrusor fibroblasts suggests a specific role of this estrogen receptor form in urothelial proliferation. Inactivation of Pten, which in turn activated the p-AKT pathway, was strictly related to the activation of the ER $\alpha$ pathway in the BOO bladders. Human relevance for these findings was provided by increased expression of $p$ AKT, PCNA, and ER $\alpha$ and decreased expression of PTEN in severe human BOO samples, compared with subnormal to mild samples. These findings clarify the involvement of estrogen excess and/or imbalance of the androgen/estrogen ratio in the molecular pathogenetic mechanisms of $\mathrm{BOO}$ and provide a novel lead into potential treatment strategies for BOO. (Am J Pathol 2011, 178:1233-1244; DOI: 10.1016/j.ajpath.2010.11.056)

A close interrelationship between lower urinary tract (bladder and urethra) symptoms, bladder outlet obstruction (BOO), and benign prostatic hyperplasia has been shown in aging men. ${ }^{1-4}$ These symptoms, which include increased voiding frequency and urgency, nocturia, incomplete bladder emptying, hesitancy, weak stream, and straining, occur in mild to severe form in 50\% to $85 \%$ of men over 50 years of age. ${ }^{5-8} \mathrm{BOO}$, which reduces or prevents the flow of urine into the urethra, and urinary tract infection, bladder cancer, and incontinence comprise the major causes of lower urinary tract symptoms. ${ }^{9,10}$ Congenital or acquired BOO can result in a stiff-walled, fibrotic bladder with low capacity, high pressure, and noncompliance, which may ultimately damage the kidneys. ${ }^{10}$ The incidence of lower urinary tract symp-

Supported by grants from the Ministry of Science and Technology (MOST; no. 2009CB941701 to X.L.), the National Natural Science Foundation of China (NSFC; no. 30671506 to X.L.), the Natural Science Foundation of Beijing Council (NSFBC; no. 7082052 to X.L.); the Ph.D. programs of Foundation of the Ministry of Education of China (MOE; no. 20070019030 to X.L.); and the Scientific Research Foundation of Graduate School of China Agricultural University (SRFGSCAU; no. KYCX09075 to W.L.); and from the Academy of Finland (N.R. and I.H.); and the Finnish Cultural Foundation at Varsinais-Suomi (N.R.).

Accepted for publication November 9, 2010

Supplemental material for this article can be found at http://ajp. amjpathol.org or at doi:10.1016/j.ajpath.2010.11.056.

Address reprint requests to Xiangdong Li, Ph.D., State Key Laboratory for Agro-Biotechnology, Faculty of Biological Sciences, China Agricultural University, Yuanmingyuan West Road No. 2, Haidian District, Beijing 100193, P.R. China. E-mail: xiangdongli@cau.edu.cn. 
toms was shown to be higher among men with prostatic enlargement, which can narrow the urethral lumen. 9,11 Despite the higher prevalence of benign prostatic hyperplasia, the detailed pathogenetic role of benign prostatic hyperplasia in inducing $\mathrm{BOO}$ remains unknown. A number of studies have demonstrated that androgens and estrogens play an important role in the development of both benign prostatic hyperplasia and BOO. ${ }^{12-16}$ Epidemiologically, BOO mainly occurs in men. ${ }^{17}$

The balance between the systemic levels of androgens and estrogens is altered in aging men. ${ }^{18-21}$ With increasing age, there is a gradual decline of androgen levels, especially the free and bioavailable testosterone. ${ }^{18,19}$ Simultaneously, estradiol $\left(E_{2}\right)$ concentrations increase, especially in obese men. ${ }^{20,21}$ Increased prevalence of $\mathrm{BOO}$ with aging suggests that estrogen (or, more precisely, the altered androgen/estrogen balance) may be involved in its pathogenesis. ${ }^{22}$ Neonatally estrogenized male mice have increased voiding frequency and a decreased ratio of urinary flow rate to bladder pressure. ${ }^{23}$ We have shown previously that male mice expressing the human Cyp19a1 gene under the human ubiquitin $\mathrm{C}$ promoter in the FVB/N genetic background $(\mathrm{AROM}+\mathrm{N})$ present with severe subfertility and cryptorchidism, ${ }^{24}$ as well as with higher mean maximal bladder pressure and decreased mean maximal flow rate, consistent with the presence of mild infravesical obstruction, but never clear signs of $\mathrm{BOO} .^{25}$

The underlying etiology of the higher prevalence of BOO with age in human remains poorly understood. ${ }^{22}$ We hypothesized that estrogen excess and/or imbalance of the androgen/estrogen ratio might have an effect on the molecular mechanisms of BOO. The only animal models reported to date are the surgically induced partial $\mathrm{BOO}$ animal model ${ }^{26}$ and the Noble rat model, in which combined testosterone and $\mathrm{E}_{2}$ treatment induced prostatic inflammation and obstructive voiding. ${ }^{27}$ Differential effects of estrogens on the male urogenital tract and spermatogenesis have been demonstrated in mice with different genetic backgrounds. ${ }^{28}$ Because the C57BI/6J mouse strain is reported to be more estrogen-sensitive than other strains, ${ }^{28}$ we hypothesized that Tg overexpression of Cyp19a1 in this background $(\mathrm{AROM}+/ 6 \mathrm{~J})$ could intensify the previously documented mild bladder intravesical obstruction observed in the FVB/N background $(\mathrm{AROM}+/ \mathrm{N})$, and would lead to full-blown $\mathrm{BOO}$, allowing us to investigate the etiology and molecular mechanisms of this condition. To demonstrate and test the relevance of the $A R O M+/ 6 \mathrm{~J}$ murine model to human $\mathrm{BOO}$ disease, we also studied severe human BOO samples for the molecular changes observed in the $\mathrm{AROM}+/ 6 \mathrm{~J}$ bladders.

\section{Materials and Methods}

\section{Transgenic Mice Expressing Human Cytochrome P450arom (CYP19A1)}

Transgenic (Tg) mice expressing human cytochrome P450arom cDNA under the control of the ubiquitin $C$ promoter in the C57BI/6J genetic background (AROM+/ $6 \mathrm{~J})$ were generated as described previously. ${ }^{29}$ Generation of the new Tg line is described in the Results section. $\mathrm{AROM}+/ 6 \mathrm{~J}$ female mice were phenotypically normal and were used as breeders. Wild-type (WT) littermate mice (C57BI/6J) were used as controls in each age group ( $n=$ $5)$. We characterized the Tg mice specifically for the BOO phenotype at three time points: 2 months $(n=6), 4$ months $(n=6)$, and 10 months $(n=10)$. For routine genotyping, PCR analysis was performed as described previously, ${ }^{29}$ using DNA extracts from ear biopsies. After weaning at the age of 21 days, the mice were housed two to four per cage, females and males separately, in a room with controlled light (12 hours of light and 12 hours of darkness) and temperature $\left(21 \pm 1^{\circ} \mathrm{C}\right)$. They were fed with soy-free mouse chow SDS RM-3 (Whitham, Essex, United Kingdom) and tap water ad libitum. The Ethics Committee for animal experimentation of the China Agriculture University approved all of the animal experiments.

\section{Morphological and Histological Analyses}

Blood from WT and AROM+/6J mice was collected by cardiac puncture, and tissues were dissected for macroscopic analyses. For histological evaluation, the bladders were fixed in $4 \%$ paraformaldehyde. In addition to bladder, we took the testes, prostate, kidneys, adrenals, pituitary, spleen, and lungs. The tissues were first fixed, then dehydrated, embedded in paraffin, and sectioned. The sections ( $5 \mu \mathrm{m}$ thick) were deparaffinized in xylene and stained with H\&E. For detecting collagen fibers, the sections were stained with Van Gieson's solution.

\section{Semiquantitative RT-PCR}

Total RNA was isolated from bladder, testis, and fibroblast using the acid phenol method, and RT-PCR was performed. One $\mu \mathrm{g}$ of total RNA was incubated with $10 \mathrm{IU}$ avian myeloblastosis virus reverse transcriptase (Promega, Madison, $\mathrm{WI}$ ) at $37^{\circ} \mathrm{C}$ for 1 hour. The cDNAs were then denatured at $95^{\circ} \mathrm{C}$ for 5 minutes and amplified through 25 cycles of PCR, using the following conditions: $94^{\circ} \mathrm{C}$ for 30 seconds, $56^{\circ} \mathrm{C}$ to $61^{\circ} \mathrm{C}$ for 45 seconds, and $72^{\circ} \mathrm{C}$ for 45 seconds. An aliquot of the RT-PCR product was subjected to agarose gel electrophoresis and was visualized by ethidium bromide staining. Three individual experiments were conducted. As an internal control for the total amount of RNA used, a 406-bp fragment of the ribosomal protein L19 gene was amplified. The primers used for the various RT-PCR analyses are given in Table 1. The density of the gel bands was quantified by using ImageJ software version 1.34 (Image processing and analysis in Java, $\mathrm{NIH}$, Bethesda, MD; http://rsb.info. nih. gov/ij/download.htm/).

\section{Whole Bladder Tissue Culture}

Whole bladders of 10-month-old WT and AROM+/6J male mice ( $n=5$ per group) were dissected out and were quickly washed in PBS. The bladders were sheared to $\sim 1 \mathrm{~cm}$ each and then were cultured in Dulbecco's 
Table 1. Primers Used for RT-PCR Analyses

\begin{tabular}{|c|c|c|c|c|}
\hline Primer name & Primer sequence & $\begin{array}{c}\text { Annealing } \\
\text { temperature }\left({ }^{\circ} \mathrm{C}\right)\end{array}$ & Plateau phase & Product size (bp) \\
\hline L19 & 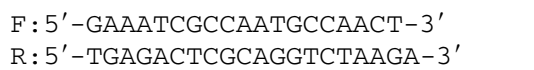 & 50 & 18 & 406 \\
\hline Aromatase & $\begin{array}{l}\mathrm{F}: 5^{\prime}-\text { ACTTCCCTAAGCCCAATG-3' } \\
\mathrm{R}: 5^{\prime}-\text { - GCCACCTACTCGATAAA-3' }\end{array}$ & 56 & 30 & 441 \\
\hline $\mathrm{ER} \alpha$ & $\begin{array}{l}\mathrm{F}: 5^{\prime}-\text { GGTCCAATTCTGACAATCGAC-3' } \\
\text { R: 5'-TTTCGTATCCCGCCTTTCATC-3' }\end{array}$ & 53 & 36 & 308 \\
\hline $\mathrm{ER} \beta$ & $\begin{array}{l}\mathrm{F}: 5^{\prime}-\text { CTTGGTCACGTACCCCTTAC-3' } \\
\mathrm{R}: 5^{\prime}-\text { GTATCGCGTCACTTTCCTTT-3' }\end{array}$ & 55 & 32 & 226 \\
\hline Col3a1 & $\begin{array}{l}\mathrm{F}: 5^{\prime} \text {-CTGAAGATGTCGTTGATGTGCAGC-3' } \\
\mathrm{R}: 5^{\prime} \text {-GATCAGGACCCCCAATGTCATAGG-3' }\end{array}$ & 57 & 22 & 343 \\
\hline PTEN & 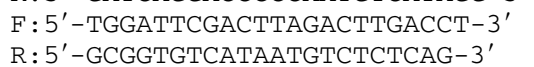 & 50 & 36 & 180 \\
\hline PCNA & $\begin{array}{l}\mathrm{F}: 5^{\prime}-\text { CAACTTGGAATCCCAGAAC-3' } \\
\mathrm{R}: 5^{\prime}-\mathrm{AGACAGTGGAGTGGCTTTT}-3^{\prime}\end{array}$ & 56 & 28 & 294 \\
\hline GPR30 & $\begin{array}{l}\mathrm{F}: 5^{\prime}-\text { GTCTTTCCGTCACGCCTAC-3' } \\
\mathrm{R}: 5^{\prime}-\text {-GCTCGTCTTCTGCTCCACA-3' }\end{array}$ & 55 & 38 & 145 \\
\hline
\end{tabular}

$F$, forward; $R$, reverse.

modified Eagle's medium (without fetal bovine serum). After 48 hours, the tissues were adherent to the wall. Then $17 \beta \mathrm{E}_{2}$ at $10 \mathrm{nmol} / \mathrm{L}$ concentration was added to the media. The cultured bladder RNA was extracted 24 hours later, and semiquantitative RT-PCR was done as described previously. ${ }^{29-31}$

\section{Embryonic Fibroblast Cell Culture}

Embryonic fibroblast cells were isolated from fetuses of $\mathrm{C} 57 \mathrm{BI}$ mice and were maintained as described previously. ${ }^{32} \mathrm{E}_{2}$ and $\mathrm{ICl} 182,780$ (ICl), PI3K inhibitor (PI3KI) were purchased from Sigma-Aldrich (St. Louis, MO). 4,4', 4"-[4-Propyl-(1H)-pyrazole-1,3,5-triyl]trisphenol (PPT; an ER $\alpha$-selective agonist) and 2,3-bis(4-hydroxyphenyl)-propionitrile (DPN; an ER $\beta$-selective agonist) were purchased from Tocris Biosciences (Tocris Biosciences, Ellisville, MO). Before ligand treatment, the medium was replaced with phenol red-free Dulbecco's modified Eagle's medium supplemented with $5 \%$ dextran charcoal-stripped fetal bovine serum for 48 hours. Fibroblast cells were treated with either $0.01 \%$ ethanol (vehicle control), $10 \mathrm{nmol} / \mathrm{L} \mathrm{E}_{2}, 10 \mathrm{nmol} / \mathrm{L} \mathrm{PPT}, 10 \mathrm{nmol} / \mathrm{L} \mathrm{DPN}$, $100 \mathrm{nmol} / \mathrm{L} \mathrm{ICl}$, or $10 \mathrm{nmol} / \mathrm{L}$ of $\mathrm{P} 13 \mathrm{KI}$ alone or in combination as $E_{2}+I C l, E_{2}+P 13 K I$, or $E_{2}+P 13 K I+I C l$ for 48 hours. For the indicated experiments, cells were pretreated with $\mathrm{ICl}$ for 8 hours before other treatments.

\section{Immunohistochemistry}

Sections ( $5 \mu \mathrm{m}$ thick) were cut from paraffin-embedded tissues and mounted on slides. After deparaffinization and rehydration in xylene and ethanol, sections were placed in $10 \mathrm{mmol} / \mathrm{L}$ citrate buffer ( $\mathrm{pH} \mathrm{6.0),} \mathrm{followed} \mathrm{by}$ heating in a microwave oven for antigen retrieval. For this step, three periods of 5 minutes each were used, after which the sections were treated with $3 \% \mathrm{H}_{2} \mathrm{O}_{2}$ in PBS $(\mathrm{pH}$ 7.6) for 10 minutes and blocked with normal goat serum (1:200 dilution) for 10 minutes. The sections were then incubated at $37^{\circ} \mathrm{C}$ for 1 to 2 hours with one of the follow- ing antibodies: p-AKT (rabbit polyclonal IgG, 1:200 dilution; sc-81433; Santa Cruz Biotechnology, Santa Cruz, CA), AKT (rabbit polyclonal IgG, 1:300 dilution; sc-5298; Santa Cruz Biotechnology), or PCNA (goat polyclonal IgG, 1:200 dilution; sc-25280; Santa Cruz Biotechnology), PTEN (rabbit polyclonal IgG, 1:200 dilution; 21057-2/ Ab-370; Signalway Antibody, Pearland, TX), ER $\alpha$ (rabbit polyclonal IgG, 1:500 dilution; Santa Cruz Biotechnology), and FSP1 (goat polyclonal IgG, 1:400 dilution; Santa Cruz Biotechnology). The primary antibody bound was detected by using biotinylated goat anti-rabbit IgG (1:200 dilution), followed by incubation with avidin-biotinperoxidase complex (Vector Laboratories, Burlingame, CA). Specific binding was visualized by using $3^{\prime}, 3^{\prime}$-diaminobenzidine tetrahydrochloride. Sections were slightly counterstained with Mayer's hematoxylin.

\section{Western Blot}

Total protein was extracted in extraction buffer [20\% glycerol, $50 \mathrm{mmol} / \mathrm{L}$ Tris- $\mathrm{HCl}(\mathrm{pH} \mathrm{6.8)}$ and 0.5\% (v/v) Tween 20] and protease inhibitor cocktail (Sigma-Aldrich) was added, followed by centrifugation at 12,000 rpm (6439 g) for 10 minutes to remove nondissolved material. Protein concentration in the supernatant was measured using a Tiangen protein assay kit (Tiangen Biotech, Beijing, China). Aliquots of protein extract containing $30 \mu \mathrm{g}$ of total protein were electrophoresed in a 10\% SDS-polyacrylamide gel electrophoresis gel and transferred to P-membrane for 3 hours with transfer buffer [25 mmol/L Tris, $192 \mathrm{mmol} / \mathrm{L}$ glycine, and $20 \%(\mathrm{v} / \mathrm{v})$ methanol]. The membrane was blocked with $2 \%$ dried nonfat milk, and incubated with antibody against $\beta$-actin, ER $\alpha$ (as above), ER $\beta$ (rabbit polyclonal IgG; ab3577; Abcam, Cambridge, MA), p-AKT (as above), AKT (as above), PCNA (as above), FSP1 (as above), PTEN (see above), or Col3a1 (mouse monoclonal IgG; sc-80564, Santa Cruz Biotechnology) in concentrations specified by the manufacturer's protocol. After treatment with primary antibody, the membrane was washed in Tris-buffered saline-Tween buffer (20 mmol/L Tris, 500 mmol/L NaCl, 0.05\% 
Tween 20) and incubated with secondary antibody (goat anti-rabbit IgG at 1:3000). Final exposure was obtained using enzymatic chemiluminescence (Amersham Pharmacia, GE Healthcare, Chalfont St Giles, UK). Finally, the films were scanned and quantified using ImageJ software, version $1.34(\mathrm{NIH})$.

\section{Human Bladder Specimens}

Twenty-six human bladder paraffin-block samples from bladder cancer patients (age, 50 to 70 years) were selected from the Pathology Department of the First Hospital of Peking University. These samples consisted of 6 cases of subnormal/mild BOO (Urodynamic system grading $0-2)^{33}$ and 20 severe $\mathrm{BOO}$ (Urodynamic system grading 6$)^{33}$ from male bladder cancer patients. Because of the difficulties in obtaining normal human bladder samples, we used the subnormal/mild BOO specimens as controls. Slides were analyzed by two expert pathologistson the basis of criteria adopted at the Department of Urology, Peking University First Hospital, Beijing, China, on the basis of an earlier report (J.L., D.Z.). ${ }^{33}$ Sections (5 $\mu \mathrm{m}$ thick) were cut from paraffin-embedded tissues and mounted on slides for further analyses.

\section{Measurement of Serum Hormones}

Serum testosterone was measured by radioimmunoassay after diethyl ether extraction, as described previously. ${ }^{34}$ Concentrations of $E_{2}$ were measured using a commercial radioimmunoassay kit (Immunotech; Beckman Coulter, Marseille, France).

\section{Statistical Analysis}

One-way analysis of variance and Tukey's and Dunnett's post hoc tests were used for statistical analyses (SPSS 12.0.1 statistical package software; SPSS, Chicago, IL). $P$ values of $<0.05$ were regarded as statistically significant. All values are presented as means \pm SEM.

\section{Results}

\section{Cyp19a1-Overexpressing Mice in the C57Bl/ 6J Genetic Background (AROM+/6J)}

We generated Tg mice expressing the human CYP19A1 cDNA under control of the human ubiquitin $\mathrm{C}$ promoter in the C57BI/6J background. The same gene construct has been used previously to generate $\mathrm{Tg}$ mice in the FVB/N genetic background. ${ }^{15}$ Standard pronuclear injection techniques were used for production of the transgenic mice, as described previously. ${ }^{29}$ Two AROM+/6J founders were produced, of which one was a severely subfertile male (small number of pups, and the positive ones were always cannibalized; the male died of bladder outlet obstruction at 10 months of age) and one fertile female. All AROM+/6J males of the $F_{1}$ generation and thereafter were severely subfertile and in general failed to produce offspring. The Tg females were fertile and were used for establishing a Tg

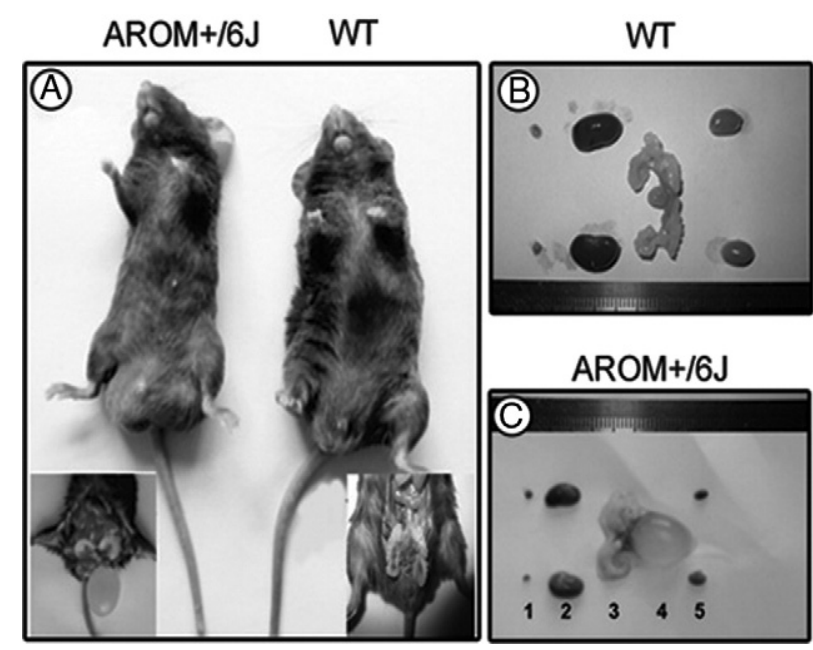

Figure 1. Phenotype of transgenic (Tg) mice expressing human CYP19A1 under the ubiquitin $\mathrm{C}$ promoter in the $\mathrm{C} 57 \mathrm{Bl} / 6 \mathrm{~J}$ genetic background $(\mathrm{AROM}+/ 6 \mathrm{~J})$. A: Inguinal herniae were observed at 2 months of age in AROM $+/ 6 \mathrm{~J}$ males with $100 \%$ penetrance $(n=16)$. Insets: Representative mouse of each group during the longitudinal laparotomy at necropsy. B and C: Complete bladder obstruction (BOO) was observed in 10-month-old male AROM $+/ 6 \mathrm{~J}$ mice with $100 \%$ penetrance $(n=10)$. Note dilated bladder filled with urine, renal hydronephrosis, and significantly smaller dark colored testes $(\mathbf{C})$, compared with wild type (B). 1, adrenals; 2, kidneys; 3, seminiferous tubules; 4 , bladder; 5 , testes. Organs in panel $\mathbf{B}$ are from a WT mouse ( $n=5$ ) during necropsy.

line. The subfertile AROM+/6J males showed no signs of abnormalities until puberty; severe inguinal herniae were evident at 2 months of age (Figure 1A). Apart from the bladder phenotype, no phenotypic differences could be found between the 2-month-old, 4-month-old, and 10month-old AROM+/6J males. Of the ten 10-month-old AROM+/6J males, five died between 9 and 10 months; the remaining five mice were sacrificed at 10 months as planned.

At necropsy, the Tg mice presented with dilated bladder filled with urine, resembling hydronephrosis, which is the equivalent extreme clinical condition of $\mathrm{BOO}$ in humans (see Supplementary Figure $\mathrm{S} 1$ at http://ajp. amjpathol.org). In addition, the Tg mice had significantly smaller and dark-colored testes, compared with WT controls [75 $\pm 21(\mathrm{Tg})$ vs $181 \pm 30 \mathrm{mg}(\mathrm{WT}) \mathrm{mg}, P<0.05]$ (Figure 1, B and C). There were no statistically significant differences in testis weight at 2 and 4 months of age. Serum $E_{2}$ levels were significantly higher in the $\mathrm{AROM}+/ 6 \mathrm{~J}$ at 2 months [95 $\pm 35(\mathrm{Tg})$ vs $10 \pm 1.6(\mathrm{WT})$ $\mathrm{pg} / \mathrm{ml}, P<0.05], 4$ months [115 $\pm 38.2(\mathrm{Tg})$ vs $12 \pm 2.1$ (WT) $\mathrm{pg} / \mathrm{ml}, P<0.05$ ], and 10 months [131 $\pm 35(\mathrm{Tg})$ vs $9.7 \pm 1.8$ (WT) $\mathrm{pg} / \mathrm{ml}, P<0.05](n=5$ to 6 for WT and $n=6$ to 10 for $\mathrm{Tg}$ ). Serum testosterone levels inversely correlated with those of $E_{2}$ and were significantly decreased in the Tg males $[0.28 \pm 0.33(\mathrm{Tg})$ vs $2.1 \pm 1.41$ (WT) $\mathrm{ng} / \mathrm{ml}, P<0.05], 4$ months $[0.43 \pm 0.38(\mathrm{Tg})$ vs $6.6 \pm 4.82(\mathrm{Tg}) \mathrm{ng} / \mathrm{ml}, P<0.05]$, and 10 months [0.38 \pm $0.48(\mathrm{Tg})$ vs $7.97 \pm 5.03$ (WT) $\mathrm{ng} / \mathrm{ml}, P<0.05]$ ( $n=5$ to 6 for WT and $n=6$ to 10 for Tg). Serum testosterone and $E_{2}$ values of $A R O M+/ 6 \mathrm{~J}$ males showed hormonal levels similar to those previously reported for $A R O M+/ N$ mice. ${ }^{29,31,35}$ 
The small testes of the 10-month-old AROM+/6J males had a phenotype identical to that previously described in $\mathrm{AROM}+\mathrm{N}$ mice, including macrophage activation, Leydig cell depletion, dysmorphic seminiferous tubules, and disrupted spermatogenesis. ${ }^{29,35}$ In contrast to the males, no major phenotypic alterations were found in the AROM+/6J females, and they presented with normal fertility with normal pregnancies, pup delivery, litter size, nursing, and offspring development. Macroscopically, the prostates of the 10 -month-old AROM+/6J males were significantly smaller, compared with WT males.

\section{Histopathological and Immunohistochemical Characterization of $\mathrm{BOO}$ in Lower Urinary Tract in AROM+/6J Male Mice}

Because urinary bladder hypertrophy is regarded as a general consequence of $\mathrm{BOO}$, we measured the bladder weights at different ages (2, 4, and 10 months) in the AROM+/6J and WT males. There was no significant difference at 2 months $[15.8 \pm 1.0(\mathrm{Tg})$ vs $16.1 \pm 1.0(\mathrm{WT})$ $\mathrm{mg}, n=5$ to 6], but we observed a progressive increase in bladder weight from 4 months $(27.4 \pm 5.1$ vs $16.6 \pm 1.8 \mathrm{mg}, \mathrm{AROM}+/ 6 \mathrm{~J}$ vs WT, $P<0.05, n=5$ to 6) to 10 months $(77.6 \pm 15.2$ vs $19.4 \pm 2.8 \mathrm{~g}$, AROM $+/ 6 \mathrm{~J}$ vs WT, $P<0.05, n=6$ for WT and $n=10$ for $\mathrm{Tg}$ ) in AROM+/6J male mice.

The increased bladder weight could be due to hyperproliferation of the urothelium of bladder and detrusor urinae muscle. On histopathological analysis, the bladder showed three- to fourfold thicker lamina propria of the detrusor in Tg males at 10 months, compared with agematched WT controls, but the smooth muscle layers of the detrusor of bladder were 70\% thinner (Figure 2, A-D) (see also Supplementary Figure $\mathrm{S} 1$ at $h$ ttp://ajp. amjpathol.org). The detrusor in AROM+/6J males also lost its normal smooth muscle layers (internal longitudinal, outer circular, and outermost longitudinal) (Figure 2, $\mathrm{E}$ and $\mathrm{F}$ ). Moreover, proliferative spindle-shaped fibroblast cells were observed to penetrate into the smooth muscle layers of the detrusor in Tg males (Figure 2F) of 10-month-old AROM+/6J males, a feature absent in agematched WT controls (Figure 2, A, C, and E). Collagen staining was abundant in the lamina propria of 10-monthold AROM+/6J males (Figure 2D), but was rather scant in WT males (Figure 2C). Histopathological analysis further demonstrated that the thickness of the striated muscle layer of the proximal rhabdosphincter in $\mathrm{Tg}$ mice was significantly $(70 \%)$ decreased in thickness, compared with age-matched controls (Figure 2, C and D).

Next, we checked proliferating cell nuclear antigen (Pcna) protein expression immunohistochemically as a marker for cell proliferation, to test whether the estrogen excess resulted in increased cell proliferation in the AROM +/6J bladders. Abundant Pcna expression was found in the layers of bladder urothelial cells and in the spindle-like cells within the AROM+/6J detrusor (Figure 2, G-J). Pcna expression also confirmed that the proliferative spindle-shaped fibroblast cells penetrated to the smooth muscle layers of the bladder detrusor in 10-
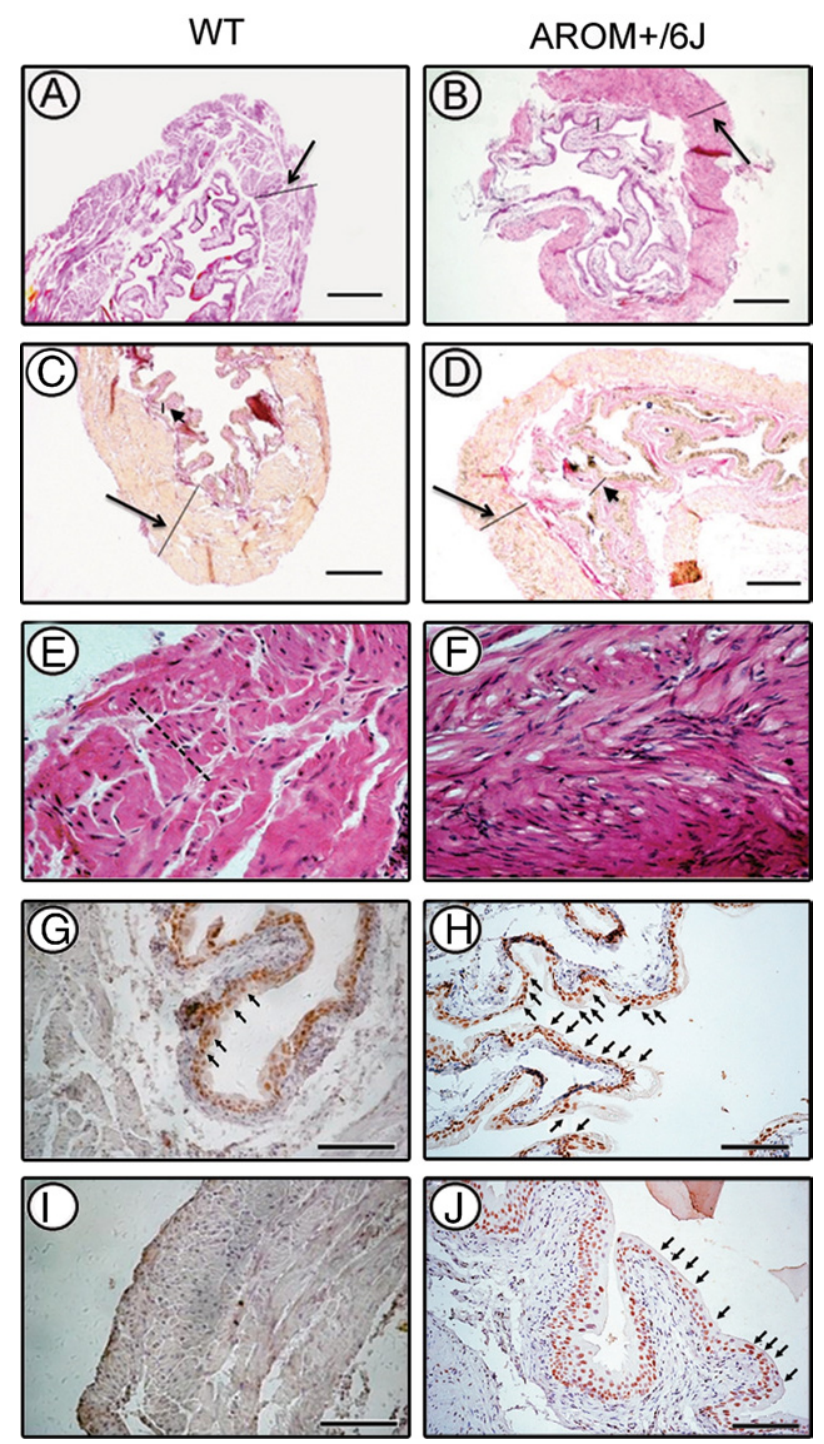

Figure 2. Histopathological and immunohistochemical (Pcna) analysis of bladder and fibrotic detrusor urinae muscle in 10-month-old WT (left panels) and $\mathrm{AROM}+/ 6 \mathrm{~J}$ males with $\mathrm{BOO}$ (right panels). A and B: $\mathrm{H} \& \mathrm{E}$ staining reveals smooth muscle of the internal longitudinal, outer circular, and outermost longitudinal layers of the detrusor (line indicated by arrow), which are $70 \%$ thinner in $\mathrm{Tg}$ mice (B) than in age-matched WT controls (A). C and D: The laminae propriae (short lines indicated by short arrows) are four times thicker in AROM $+/ 6 \mathrm{~J}$ mice (D) than in WT mice $(\mathbf{C})$, but fibrosis, characterized by pink-red collagen by Van Gieson staining, was observed in the $\mathrm{AROM}+/ 6 \mathrm{~J}$ mice (D) both in the lamina propria (short line) and throughout the detrusor (long line indicated by long arrow). $\mathbf{E}$ and $\mathbf{F}$ : H\&E staining reveals abundant fibrosis in disorganized, extensively shortened, and hard-to-distinguish layers of lamina propria of smooth muscle layers of detrusor in 10-month-old AROM $+/ 6 \mathrm{~J}$ mice $(\mathbf{F})$, compared with WT (E). Dashed line indicates the muscle thickness and layer arrangement (E). G-J: Immunohistochemistry for Pcna in urothelium and intradetrusor fibroblasts of bladder in 10-month-old AROM+/6J Tg and WT mice. Abundant nuclear staining of Pcna protein expression (arrows indicate a representative selection of the abundant positive staining) was found in multilayers of bladder urothelial cells and in Tg mice proliferative spindle-shaped fibroblast cells (H) penetrating the smooth muscle layers of the bladder detrusor in Tg males (J). Scant Pcna stained cells could be found in WT detrusor (G), but not in fibroblasts (I). Scale bars: $50 \mu \mathrm{m}(\mathbf{A}-\mathbf{F}) ; 20 \mu \mathrm{m}(\mathbf{G}-\mathbf{J})$

month-old AROM+/6J males (Figure 2, $\mathrm{H}$ and J). Scant Pcna-stained cells could be found only in WT detrusor. not in fibroblasts (Figure 2, G and I). Morphometric analysis with ImageJ software revealed that $\sim 20 \%$ of cells 
A

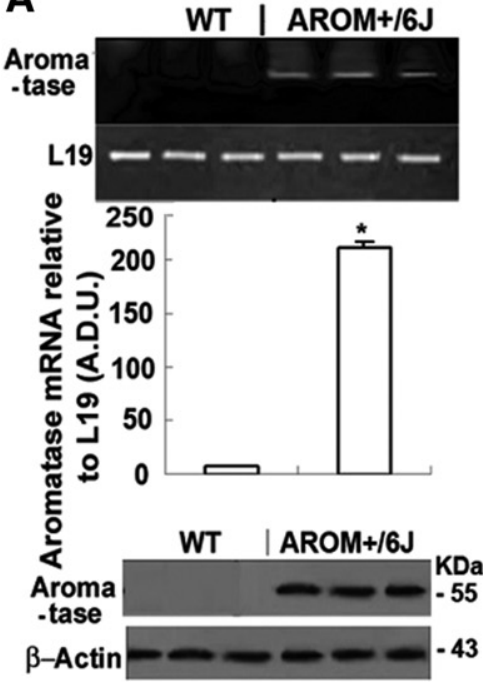

D
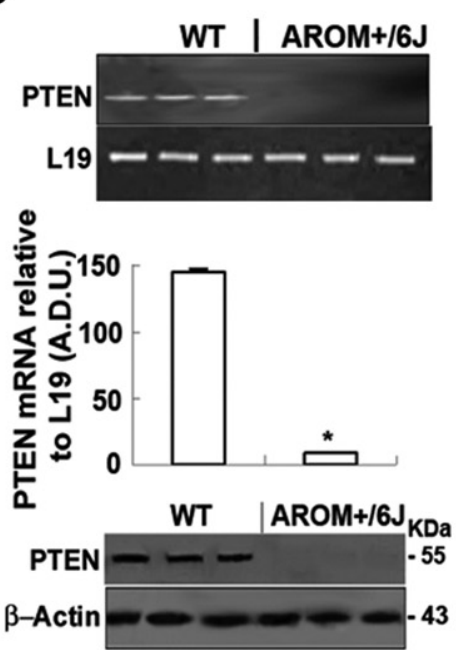

B
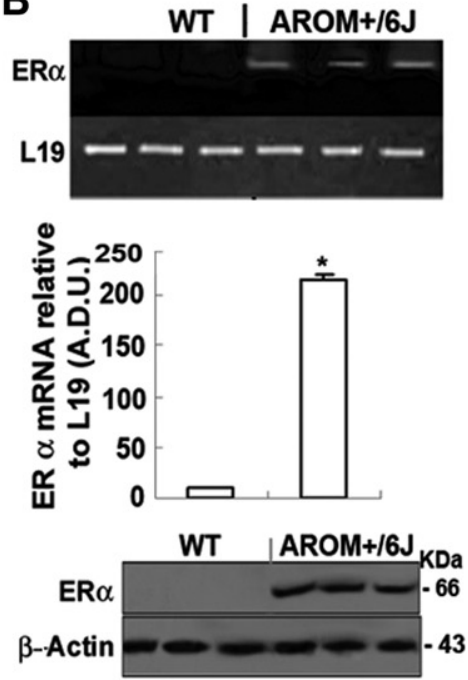

E
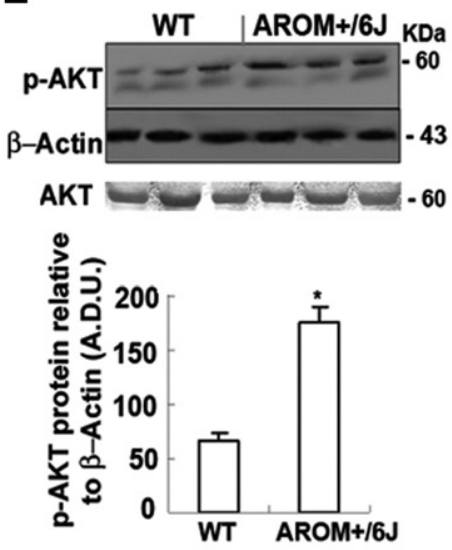

C
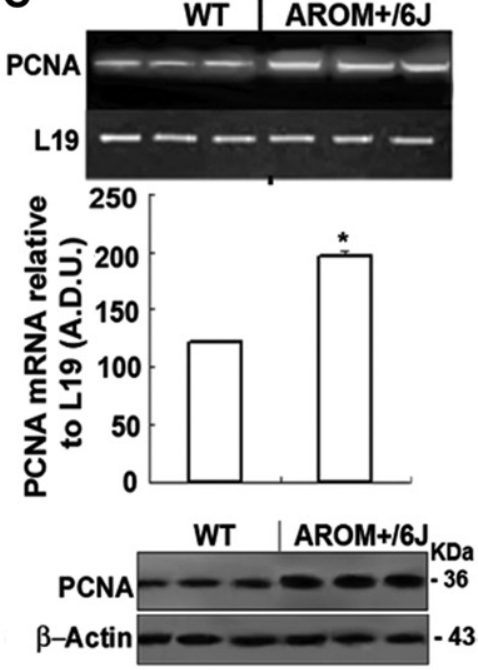

$\mathbf{F}$
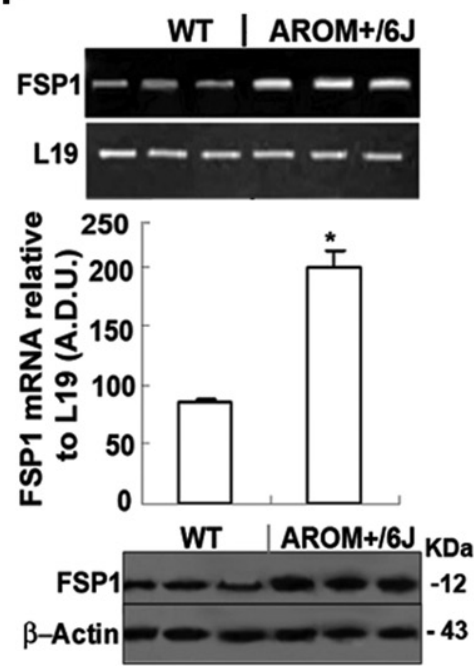

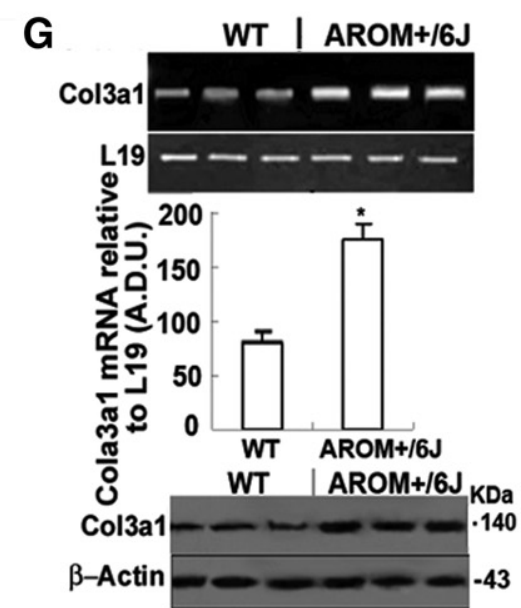

H

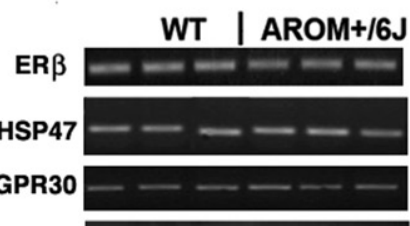

L19

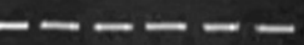

Figure 3. Expression of selected estrogen-related genes in the bladder of 10-month-old wild-type (WT) and transgenic AROM+/6J males at mRNA (A-D F-H) and protein (A-G) levels. The upper blots show RT-PCR mRNA data for aromatase (Cyp19a1) (A), Esr1 (alias ER $\alpha)$ (B), Pten (C), Pcna (D), Fsp1 (F), Col3a1 (G), Esr2 (alias ErR), Serpinh1 (alias Hsp47), and Gpr3O (H), with L19 as internal control. Data shown are for three WT and transgenic mice, using $1 \mu \mathrm{g}$ of RNA extract per lane, and are representative data from one of three similar experiments. The center graphs (A-G) show densitometric quantification of the specific mRNA amplicons corrected for intensity of the L19 amplicon. Each bar represents the mean \pm SEM of three independent experiments in triplicates. A.D.U., arbitrary densitometric units. ${ }^{*} P<0.05$ (10-month-old AROM+/6J vs age-matched WT male bladder). The lower blots (A-D, F, and G) show protein bands by Western blot analysis, with molecular weight indicated (kDa). In E, the upper blots display bands for phosphorylated AKT (p-AKT). Protein extracts ( $30 \mu \mathrm{g}$ per lane) from WT and $\mathrm{AROM}+/ 6 \mathrm{~J}$ male mouse bladders $(n=3$ for each) were analyzed and each experiment was repeated three times. Representative data from one of three similar experiments are shown. $\beta$-actin was applied as internal control, and expression levels were normalized to $\beta$-actin protein. * $P<0.05$ (WT vs AROM $+/ 6 \mathrm{~J}$ ). 
stained positive for Pcna/total cells in AROM+6J male bladders, compared with $\sim 2 \%$ staining positive for Pcna cells in the WT control ( $n=6 /$ group). The proportionof Pcna-positive cells out of total cells in detrusor was 0.268 \pm 0.009 in $A R O M+/ 6 \mathrm{~J}$, compared with $0.019 \pm 0.003$ in WT $(P<0.05)$.

\section{Differential Gene Expression in AROM+/6J Male Bladder and Molecular Mechanisms of $\mathrm{BOO}$}

We first confirmed Cyp19a1 expression in the urogenital tract, in total RNA isolated from testis, bladder, and urethra. As in a previous study, ${ }^{29} \mathrm{Tg}$ Cyp19a1 mRNA was detected in the bladder (Figure $3 \mathrm{~A}$ ), testis, and prostate of $A R O M+/ 6 \mathrm{~J}$ males. To determine the local hormonal factors thought to be involved in the bladder phenotype of the Tg males, we checked the expression of nuclear estrogen receptors $\alpha$ and $\beta$ in the bladder. At both the mRNA and the protein level, ER $\alpha$ was markedly upregulated in the $\mathrm{Tg}$ male bladder at 4 and 10 months (Figure 3B). No significant differences in ER $\beta$ levels in the bladders were found between the AROM+/6J and WT controls, or between 4-month-old and 10-monthold AROM +/- 6J male bladders (Figure 3H) (see also Supplementary Figure S2 at http://ajp.amjpathol.org). Pcna mRNA and protein were significantly up-regulated in both 4-month-old and 10-month-old AROM+/6J male bladders (Figure 3C).

We also measured expression in the bladder of the $\mathrm{G}$ protein-coupled receptor 30 gene (Gpr30), which has been shown to be a relevant candidate to mediate nongenomic estrogen actions. ${ }^{36}$ No significant differences in Gpr30 mRNA expression levels were found between the AROM+/6J and WT controls (see Supplementary Figure S2 at $h$ ttp://ajp.amjpathol.org). Next, we checked whether Pten expression was altered, because this gene is important in estrogen-dependent cell survival and apoptosis ${ }^{16,17}$ and is frequently mutated in estrogen-dependent diseases. ${ }^{16,18} \mathrm{~A}$ significant down-regulation or total loss of Pten expression was found in both the 4-month-old and the 10-monthold $\mathrm{BOO} \mathrm{AROM}+/ 6 \mathrm{~J}$ male bladders (Figure 3D). Because PI3K/AKT is the direct downstream target for PTEN in cytoplasm, the next step was to investigate whether the PI3K/AKT signaling pathway (which is suppressed by PTEN through estrogen-induced action) was altered. As expected, Western blotting showed that $\mathrm{p}$-AKT protein expression was significantly upregulated in both 4-month-old and 10-month-old Tg male bladders (Figure 3E), but no significant changes were observed in total Akt between the groups (Figure 3E).

Because activated fibroblasts are the key mediators of fibrosis, we investigated the induction of fibroblasts during the development of fibrosis in the detrusor, by analyzing fibroblast-specific markers HSP47 (encoded by the Serpinh1 gene) and FSP1 (encoded by the S100a4 gene) in the bladder. FSP1 was significantly up-regulated in the detrusor (Figure 3F), but no differ-
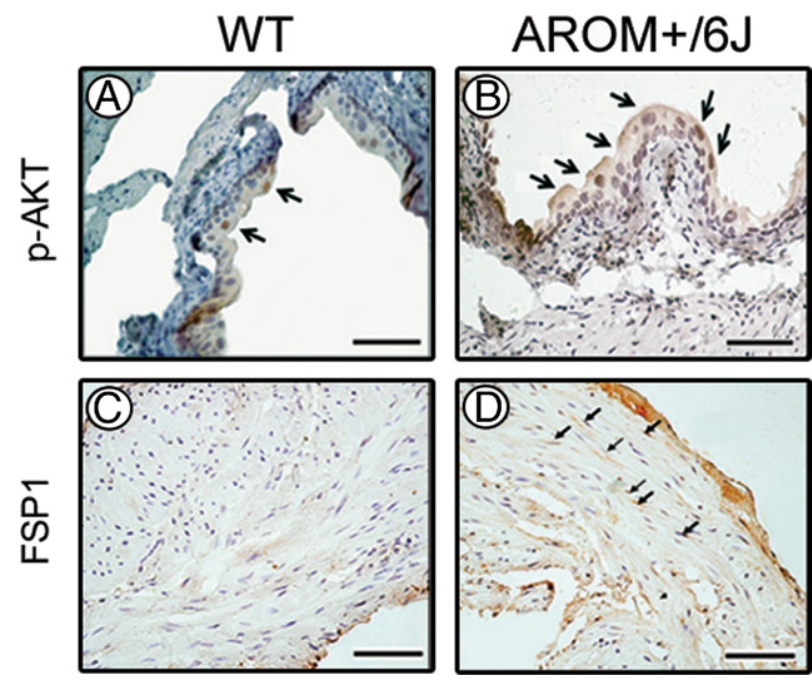

Figure 4. Immunohistochemical analyses for p-AKT (A and B) and FSP1 (C and $\mathbf{D}$ ) in 10-month-old AROM+/6J (B and $\mathbf{D})$ and age-matched WT (A and C) male bladder. A: Only a few single weak p-AKT-positive stained cells were detected in WT age-matched control littermate bladder urothelia. B: Abundant p-AKT protein (arrows) nuclear staining expression in the hyperproliferated urothelial cells of 10-month-old AROM + $6 \mathrm{~J}$ male bladder could be found, but not in spindle-shaped fibroblast cells. C: No positive stained cells could be detected in WT age-matched control littermates. D: FSP1 protein (arrows) nuclear staining was expressed only in the proliferative spindle-shaped fibroblast cells which penetrated to the smooth muscle layers of the bladder in 10-month-old AROM $+/ 6 \mathrm{~J}$ males. Scale bars $=20 \mu \mathrm{m}$

ences were found in HSP47 between Tg and WT tissues (Figure $3 \mathrm{H}$ ).

Type I and III collagens are most abundant in the bladder wall. Because these proteins are the major tension-bearing structural elements in the urinary bladder, a proper type I/type III ratio is critical for normal function of the bladder. Type III collagen was significantly up-regulated in the $\mathrm{Tg}$ bladder samples (Figure 3G).

Immunohistochemical staining revealed abundant $\mathrm{p}$ AKT protein in the hyperproliferated urothelial cells but not in the spindle-shaped fibroblast cells of 10-monthold Tg male bladder (Figure 4B), which supports the findings on $\mathrm{p}-\mathrm{AKT}$ by Western blotting (Figure $3 \mathrm{G}$ ). Only scattered $\mathrm{p}$-AKT-positive cells were detected in age-matched WT samples (Figure 4A). Immunohistochemistry for FSP1 was consistent with the Western blotting analysis (Figure 3E), further confirming the location of spindle-shaped FSP1-positive cells only in the $\mathrm{Tg}$ detrusor (Figure 4D).

\section{Mechanisms of Estrogen Action in Vitro in the Bladder}

We evaluated in primary culture the expression of a subset of genes with possible relevance to the transcriptional events in response to local estrogen action in the bladder. The experiments were performed 2 days after plating of the 10-month-old AROM+/6J bladder cells. We have previously tested different doses of $E_{2}(1 \mathrm{nmol} / \mathrm{L}, 10 \mathrm{nmol} / \mathrm{L}, 100 \mathrm{nmol} / \mathrm{L})$, and the $10 \mathrm{nmol} / \mathrm{L}$ dose was chosen for further experiments, based on earlier findings ${ }^{26}$ and also because it was 
A
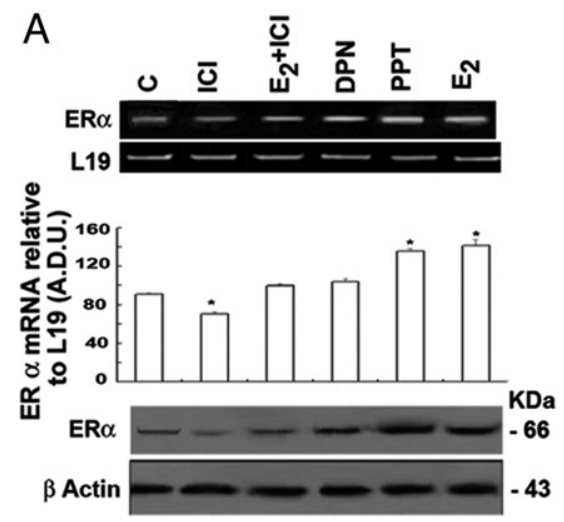

D

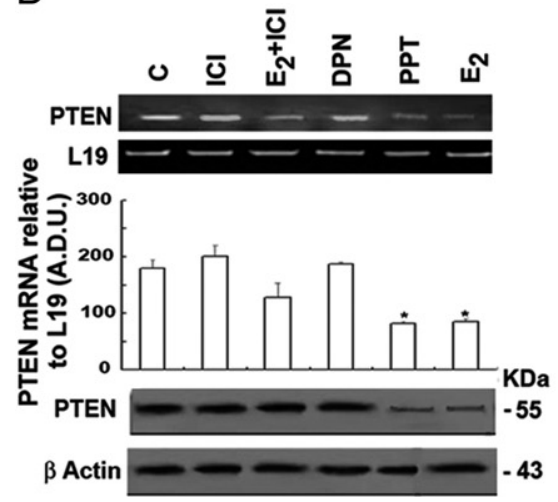

B
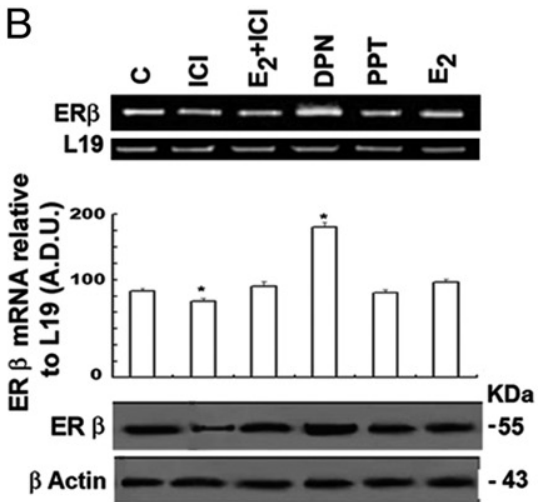

$E$

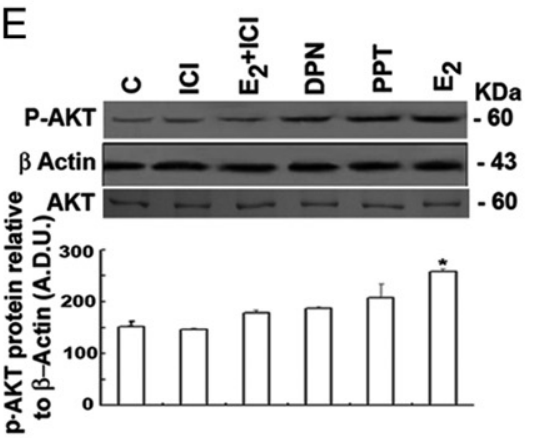

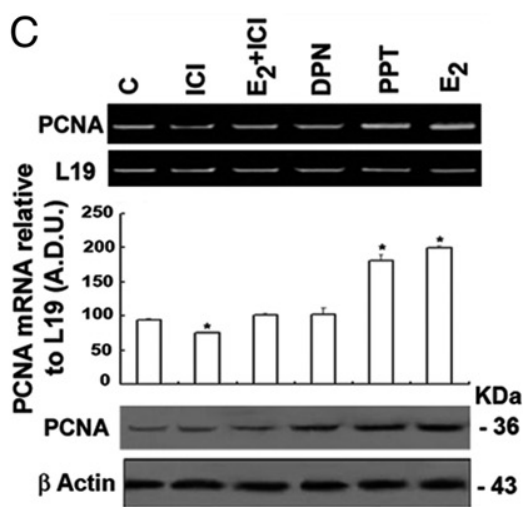

F

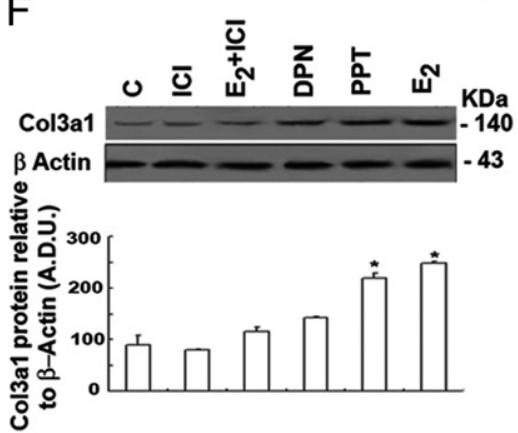

Figure 5. Expression of estrogen-related genes at mRNA (A-D) and protein $(\mathbf{A}-\mathbf{F})$ levels in cultured 10-month-old AROM+/6J male bladder with different treatments: C, vehicle; ICI, estrogen receptor antagonist; PPT, ER $\alpha$ agonist; DPN, ER $\beta$ agonist. A-D: The upper blots show representative RT-PCR mRNA data for Es $r 1$ (alias ER $\alpha$ ) (A), Esr2 (alias ERß) (B), Pcna (C), and Pten (D), with L19 as internal control. The remaining blots (lower for A-D; upper for $\mathbf{E}$ and $\mathbf{F}$ ) show protein bands by Western blot analysis, with molecular weight indicated $(\mathrm{kDa})$. The graphs show the densitometric quantification. A.D.U., arbitrary densitometric units. Other details are as for Figure 3. ${ }^{*} P<0.05$, for PPT vs C, $\mathrm{E}_{2}$ vs C, ICI vs C (ER $\alpha$ and Pcna in $\mathbf{A}$ and $\left.\mathbf{C}\right)$; for DPN vs C (ER $\beta$ in $\mathbf{B}$; for PPT vs C, $\mathrm{E}_{2}$ vs C (Pten and Col3a1 in $\mathbf{D}$ and $\left.\mathbf{F}\right)$; and for $\mathrm{E}_{2}$ vs C (p-AKT in $\left.\mathbf{E}\right)$.

most effective in up-regulating Cyr61 expression (see Supplementary Figure S3 at http://ajp.amjpathol.org). Treatment of the cultures with $\mathrm{E}_{2}$ and the $\mathrm{ER} \alpha$ agonist PPT $(10 \mathrm{nmol} / \mathrm{L})$ for 24 hours resulted in up-regulation of $\mathrm{ER} \alpha$, whereas the $\mathrm{ER} \beta$ agonist DPN (10 nmol/L) had no effect (Figure 5A). ER $\beta$ was up-regulated only by the latter compound, and not by any other treatments (Figure 5B). ER $\alpha$ and $\mathrm{ER} \beta$ expressions were significantly down-regulated by the combined $\mathrm{ER} \alpha$ and $\mathrm{ER} \beta$ inhibitor ICI 182,780 (100 nmol/L) (Figure 5, A and B). The addition of $\mathrm{ICl}$ blocked the up-regulation of $\mathrm{ER} \alpha$ expression induced by $\mathrm{E}_{2}$ and PPT $\left(P<0.05, \mathrm{E}_{2}+\mathrm{ICl}\right.$ vs $E_{2}$ or PPT) (Figure $5 A$ ), but had no effect on ER $\beta$ expression (Figure 5B). In response to the stimulations, the Pcna gene showed identical expression pattern with ER $\alpha$ (Figure $5 \mathrm{C}$ ), which may implicate Pcna as the direct gene target for estrogen receptors (more precisely, ER $\alpha$ ). Moreover, Pten expression was significantly down-regulated with $\mathrm{E}_{2}$ and/or the $\mathrm{ER} \alpha$ agonist PPT (Figure 5D). When stimulated for a short period (30 minutes), $E_{2}$ had no effect, suggesting that the rapid nongenomic regulatory pathway for AKT phosphorylation was not activated. P-AKT protein expression was up-regulated significantly in the bladder cells after 24 hours of culture in the presence of $E_{2}$ and/or the $E R \alpha$ agonist PPT (Figure 5E), but no significant differences were observed in total AKT between the groups (Figure $5 \mathrm{E})$. Moreover, $\mathrm{E}_{2}$ significantly up-regulated Col3a1 expression in the cultures, and this effect was suppressed by cotreatment with $\mathrm{ICI}$ (Figure 5F).

\section{Estrogen Induces Fibroblast Activation in Vitro}

We isolated embryonic fibroblasts from WT C57BI/6J fetuses as described previously ${ }^{32}$ and cultured them in vitro. p-AKT protein expression was not found in either $\mathrm{AROM}+/ 6 \mathrm{~J}$ or WT C57BI/6J embryonic fibroblast. Both $E_{2}$ and the ER $\alpha$ agonist PPT significantly up-regulated $\mathrm{ER} \alpha$ expression, but this effect was lost in the presence of ICI or ICI + PI3KI (Ly294002 or PI3KI; PI3K inhibitor) (Figure 6A). PPT also significantly up-regulated ER $\alpha$ mRNA expression, and addition of $\mathrm{ICl}+\mathrm{PI} 3 \mathrm{KI}$ to $\mathrm{E}_{2}$ blocked this effect (Figure 6A). Consistent with the data on primary bladder cultures, $\mathrm{E}_{2}$ and PPT, but not DPN, significantly induced cell proliferation (up-regulation of Pcna) (Figure 6B). This $\mathrm{E}_{2}$ effect was profoundly suppressed by $\mathrm{ICl}$ or ICI + PI3KI (Figure 6B).

To verify whether the fibroblast proliferation correlated with $E_{2}$ stimulated accumulation of collagen, we examined Col1 and Col3a1 expression. $\mathrm{E}_{2}$ (as well as PPT, but not DPN) significantly up-regulated Co/3a1 mRNA and protein expression, and this $E_{2}$ effect was significantly 
A

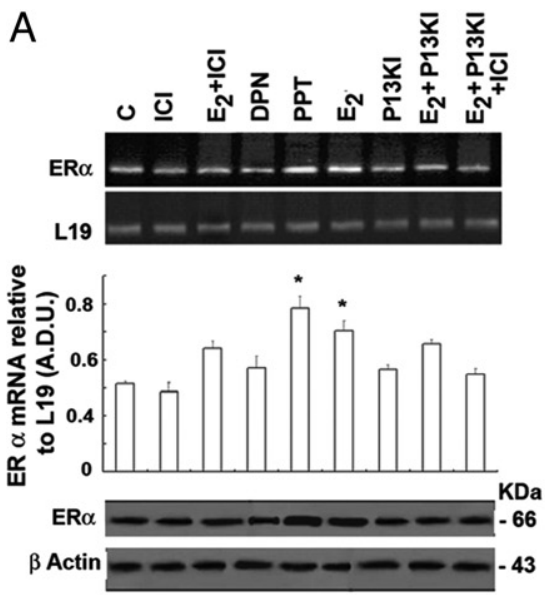

D

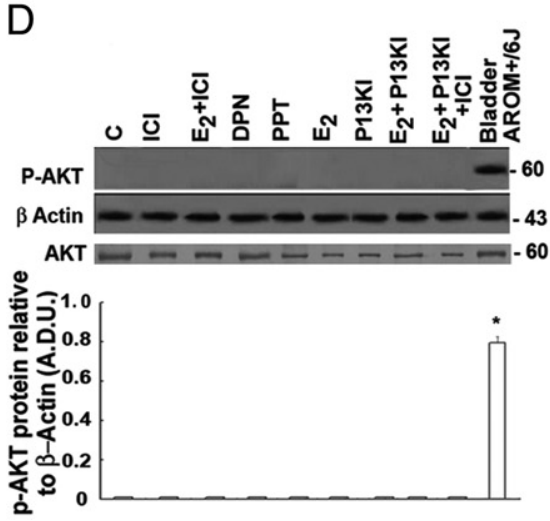

B
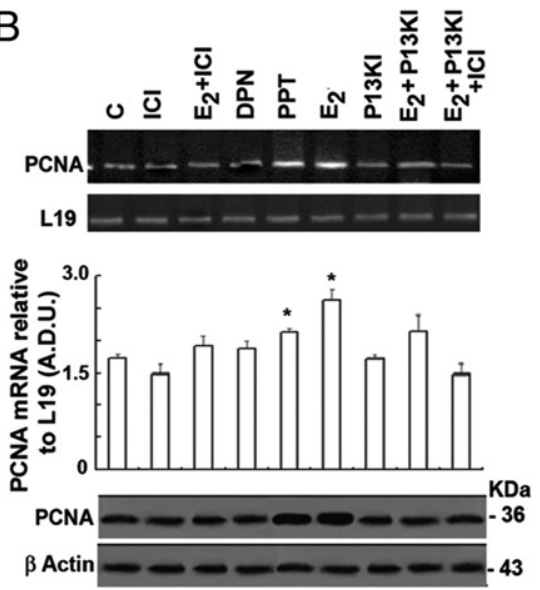

C

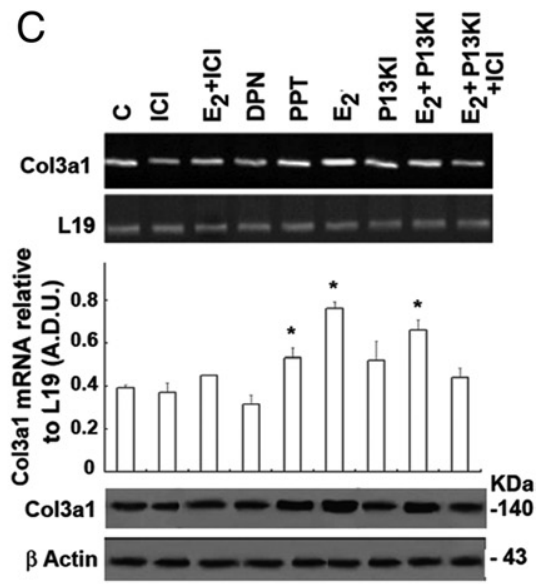

Figure 6. Expression of estrogen-related genes at mRNA $(\mathbf{A}-\mathbf{C})$ and protein $(\mathbf{A}-\mathbf{D})$ levels in cultured embryonic fibroblasts from $\mathrm{C} 57 \mathrm{Bl}$ mouse fetuses with different treatments. A-C: The upper blots show representative RT-PCR mRNA data for $\mathrm{ER} \alpha(\mathbf{A})$, Pcna (B), and Col3a1 (C), with L19 as internal control, from three individual fetal fibroblast cultures treated with different compounds: C, vehicle; ICI, estrogen receptor antagonist ICI; PPT, ER $\alpha$ agonist; DPN, ER $\beta$ agonist; PI3KI (Ly294002), PI3K antagonist. The remaining blots (lower for $\mathbf{A}-\mathbf{C}$; upper for $\mathbf{D}$ ) show protein bands by Western blot analysis, with molecular weight indicated $(\mathrm{kDa})$. The graphs show the densitometric quantification. A.D.U., arbitrary densitometric units. ${ }^{*} P<0.05$, for PPT vs $\mathrm{C}, \mathrm{E}_{2}$ vs $\mathrm{C}$ (ER $\alpha$ and Pcna in $\mathbf{A}$ and $\left.\mathbf{B}\right)$; for PPT vs C, $\mathrm{E}_{2}$ vs $\mathrm{C}$ and $\mathrm{E}_{2}+\mathrm{P} 13 \mathrm{KI}$ vs $\mathrm{C}(\mathrm{Col} 3 \mathrm{a} 1$ in $\mathbf{C})$; and for AROM+/6J bladder vs C (p-AKT in D).

suppressed by $\mathrm{ICl}$. $\mathrm{E}_{2}$-mediated and/or PPT-mediated fibroblast proliferation and fibrogenesis did not have any effect on the p-AKT and/or total AKT protein levels in the embryonic fibroblast cultures (Figure 6D). Consistent with the lack of $\mathrm{p}$-AKT protein expression in the spindleshaped fibroblast cells of 10-month-old Tg male bladder (Figure 6A), the gene expression changes measured in primary fibroblast cell culture exposed to $\mathrm{E}_{2}$ stimulation in vitro were mediated mainly by estrogen receptors, and most predominantly via $\mathrm{ER} \alpha$, whereas no further activation of $\mathrm{p}$-AKT took place.

\section{Similarities in Gene Expression Changes between Murine AROM+/6J and Human Male BOO Bladders}

To demonstrate the relevance of the $\mathrm{AROM}+/ 6 \mathrm{~J}$ murine model for human BOO disease, we analyzed the same molecular changes observed in the AROM+/6J in human $\mathrm{BOO}$ samples. We analyzed the protein expression of ER $\alpha$, PTEN, PCNA, and p-AKT immunohistochemically in severe $(n=20)$ and subnormal/mild $(n=6)$ human BOO bladder paraffin-block samples. The ER $\alpha$-positive urothelial cells were markedly increased in severe BOO male bladders (Figure 7B), compared with subnormal/mild bladder samples (Figure 7A). PCNA-positive cells were markedly increased in the severe $\mathrm{BOO}$ male bladder samples (Figure 7D), compared with the subnormal ones
(Figure 7C). We were not able to detect any staining for PTEN-positive cells in either subnormal/mild or severe BOO male bladders (data not shown). Because PI3K/ AKT is the direct downstream target for PTEN in cytoplasm, the next step was to investigate whether the PI3K/ AKT signaling pathway was altered in human BOO patients. As expected, immunohistochemical staining showed abundant p-AKT expression in the hyperproliferated urothelial cells, but not in the spindle-shaped fibroblast cells in severe human male $\mathrm{BOO}$ (Figure 7F), and only a few single cells staining positive were found in the subnormal/mild group (Figure 7E).

\section{Discussion}

The present study showed that $\mathrm{AROM}+/ 6 \mathrm{~J}$ males presented with severe inguinal herniae at 2 months of age, with urine-filled dilated bladder and hydronephrosis, reduced testis size, and finally with complete BOO at 10 months of age. The prostates of these mice were significantly smaller, so BOO could not be due to any mechanical obstruction of urethra due to benign prostatic hyperplasia and consequent dilatation of bladder. In 10-month-old AROM+/6J males, histopathological analyses revealed hypertrophic bladder with thicker lamina propria and detrusor atrophy with disorganized muscle layers. Moreover, the fibrosis penetrated throughout detrusor of the bladder. These results are in 


\section{Mild/subnormal Severe}
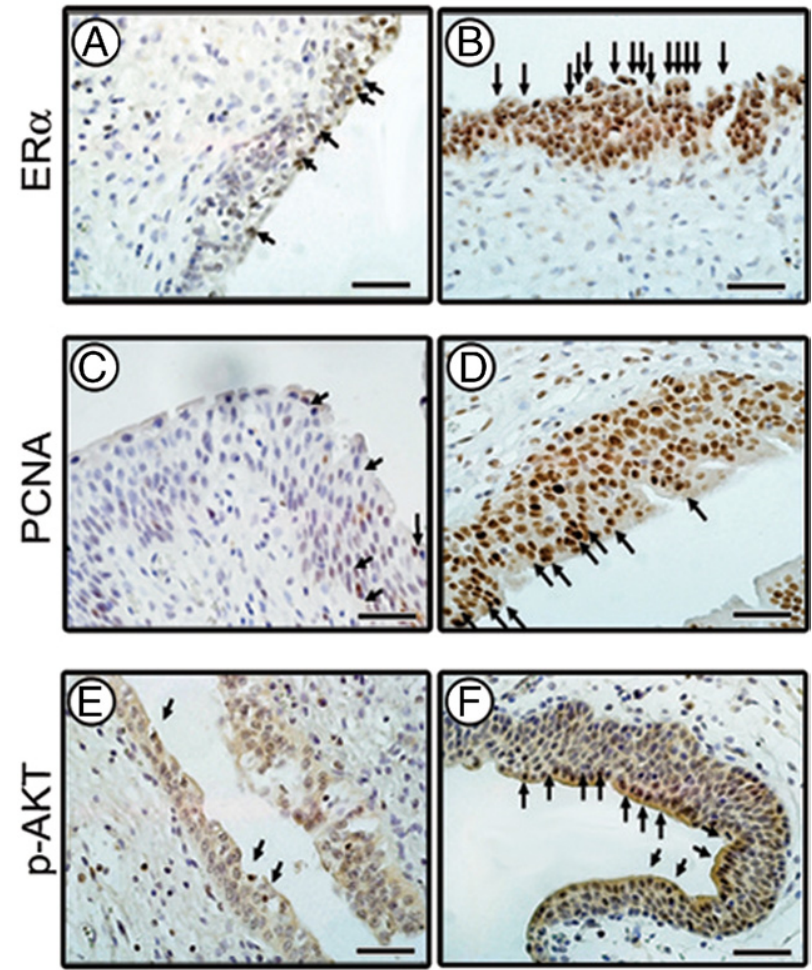

Figure 7. Immunohistochemical analyses for ER $\alpha$, PCNA, and p-AKT in severe and subnormal/mild human male BOO bladder paraffin-block samples. Representative data from a total of 6 subnormal $/ \mathrm{mild}$ and 20 severe $\mathrm{BOO}$ samples are presented. The $\mathrm{ER} \alpha$-positive urothelial cells were markedly increased in number in all severe BOO male bladders (B), compared with subnormal/mild bladder samples (A). PCNA-positive nuclear stained cells were markedly increased in the severe BOO male bladder (D), compared with subnormal ones $(\mathbf{C})$. Abundant p-AKT expression in the hyperproliferated urothelial cells, but not in the spindle-shaped fibroblast cells in severe human male BOO (F), whereas only a few single cells stained positive in the subnormal/mild group (E). Arrows indicate positively stained cells (in severe BOO samples, only a representative selection of the abundant positively stained cells). Scale bar $=20 \mu \mathrm{m}$.

agreement with prior studies and indicate disorganized detrusor structures in BOO. ${ }^{36,37}$ Abundant expression of the cell proliferation marker Pcna supported the histopathological signs of hyperplasia of the bladder urothelium and fibroblasts, responsible for the increased bladder weight. This confirmed findings from earlier studies, in which hyperplasia of the epithelium and fibroblasts were observed in animals with BOO. ${ }^{14,37}$

Under normal conditions, urothelium belongs to the slowest growing epithelial cell types in the renal pelvis, urethra, and bladder (despite reports of estrogen-induced proliferation ${ }^{38,39}$ ). Our data showed estrogen-induced urothelial cell proliferation both in vivo and in vitro. In contrast to the muscle cell hyperplasia frequently observed in $\mathrm{BOO},{ }^{40,41}$ the detrusor in $\mathrm{AROM}+/ 6 \mathrm{~J}$ mice undergoes atrophy at 10 months of age. Similarly to $\mathrm{AROM}+/ \mathrm{N}$ males, ${ }^{29,35}$ the $\mathrm{AROM}+/ 6 \mathrm{~J}$ males showed high serum $E_{2}$ and low testosterone levels, decreased androgen/estrogen ratio, and disrupted reproductive development and spermatogenesis, putatively due to estrogen susceptibility of the C57BI/6J genetic background. ${ }^{28}$ Androgen receptor has been detected in bladder detru- sor, ${ }^{42}$ and muscle cells showed androgen response. Thus, the detrusor muscular atrophy in the AROM+/6J mice could have also resulted from androgen deficiency and decreased androgen/estrogen ratio.

Expression of $E R \beta$ is predominantly distributed in the male urinary tract, such as the bladder, urethra, and prostate, whereas ER $\alpha$ expression is scarcely detectable in the rodent male bladder. ${ }^{23,42,43}$ No abnormalities in voiding function could be found in $E R \alpha^{-/-}, E R \beta^{-/-}$, or in estrogen receptor double-knockout (ie, both $E R \alpha$ and $E R \beta)$ male mice. ${ }^{44}$ In the present study, we found that $E R \alpha$ was up-regulated in 10-month-old $\mathrm{AROM}+/ 6 \mathrm{~J}$ male obstructed bladder, suggesting a possible local estrogen action resulting in bladder malfunction via $\mathrm{ER} \alpha$ counteracting androgen effects in the bladder locally. In turn, this possibly caused chronic irritation and consequent development of infravesical obstruction in the lower urinary tract of the AROM+/6J males at 10 months of age.

In addition to the well-characterized classical nuclear receptors, a growing body of evidence suggests that rapid estrogen actions are mediated by estrogen-binding proteins on the plasma membrane. ${ }^{36}$ An orphan $G$ protein-coupled receptor, GPR30, has been identified as a relevant candidate for the estrogen membrane receptor. ${ }^{36}$ Estrogens could activate the cytosolic PI3K/AKT signaling pathway, leading to increased level of $\mathrm{p}-\mathrm{AKT}$. We were unable to detect differential expression of Gpr30 in AROM+/6J bladder, both in vivo and in vitro. Moreover, in both WT and AROM+/6J bladder the known Gpr30 agonist $\mathrm{ICl}$ was also unable to induce Gpr30 expression in vitro.

Loss of PTEN expression or PTEN mutations have been shown in estrogen related cancers. ${ }^{45-47}$ The prevalent paradigm is that AKT phosphorylation is negatively regulated by PTEN. $E_{2}$-induced reduction of PTEN expression has been reported in hepatocytes by Marino et al. ${ }^{48}$ Their studies showed that ER-dependent AKT phosphorylation is paralleled by a decrease of PTEN level. In the present study, we showed clear down-regulation of Pten expression both in $\mathrm{AROM}+/ 6 \mathrm{~J}$ bladder tissue and in estrogen-treated bladder cultures in vitro, confirming the role of PTEN in mediating estrogen action. Blockage of the ER $\alpha$ pathway inactivated the PTEN/p-AKT pathway in the BOO bladders. In bladder culture, we demonstrated that $E_{2}$ action in the intradetrusor fibroblast proliferation was mediated through $E R \alpha$ only. Our findings are in agreement with a previous study in $E R \alpha^{-1-}$ mice, in which estrogen/ER $\alpha$ did activate the phosphorylation of AKT and lack of ER $\alpha$ did not produce phosphorylation of AKT in endometrial cells. ${ }^{49}$

We also demonstrated that estrogen remodels the bladder detrusor through fibroblast activation, as characterized by increased fibroblast cell proliferation and altered collagen III synthesis. $\mathrm{E}_{2}$ could modulate fibroblast activation via estrogen receptor, which was supported by the result that $\mathrm{ICl}$ could prevent the $\mathrm{E}_{2}$ induced activation in fibroblast culture. However, the mechanism how $\mathrm{E}_{2}$ could activate fibroblasts remains unknown and calls for studies with other coregulators involved in $E_{2}$ and estrogen receptor activity. The imbalance of collagen III/I synthesis may play a major 
role in bladder smooth muscle remodeling. Decreases in type III/type I ratio are reported to alter the fiber size in detrusor, resulting in a more compliant bladder in collagen-deficient mice. ${ }^{50}$ Some clinical studies have reported type III collagen up-regulation and an increase in type III/I ratio in noncompliant fibrotic human bladders. ${ }^{51,52}$ Nonetheless, how type III collagen upregulation could lead to bladder dysfunction remains controversial. In the present study, we demonstrated that estrogen activated intradetrusor fibroblasts, which in turn, increased the proliferation of fibroblasts and up-regulated collagen III expression and may have caused bladder deformation and dysfunction in $\mathrm{BOO}$ of the AROM+/6J males.

In accord with a recent study on sex steroid receptors in male human bladder by Chavalmane et al, ${ }^{53}$ we also detected ER $\alpha$ expression in human bladder. The number of $\mathrm{ER} \alpha$-positive urothelial cells was markedly increased in severe BOO human male bladders, compared with subnormal/mild human BOO bladders. Also, the number of PCNA-positive cells was markedly increased in severe BOO male bladders. We could not, however, detect any PTEN-positive cells in either subnormal/mild or severe human BOO male bladders. A plausible explanation for the lack of PTEN expression could be that all patients whose samples were studied had bladder cancer. The molecular pathogenesis of the hyperproliferation of urothelial cells in bladder cancer, although showing signs of increased estrogen action, may not be identical with that observed in our mouse model. As expected, abundant $\mathrm{p}$-AKT-positive cells were found in the hyperproliferated urothelium in severe human $\mathrm{BOO}$, but not among the spindle-shaped fibroblast cells. These findings are in agreement with observations in our AROM+/6J murine model, supporting the human relevance of the model. Although it might be too early to draw definitive conclusions about the etiological role of estrogens in human $\mathrm{BOO}$, larger-scale clinical investigations on the relationship would be appropriate, on the basis of the present findings.

Fibroblast proliferation was specifically triggered by $\mathrm{E}_{2}$ causing accumulation of collagen in primary fibroblast culture. $\mathrm{E}_{2}$ (through $\mathrm{ER} \alpha$ ) significantly up-regulated Col3a1, and this $E_{2}$-mediated effect was suppressed by $\mathrm{ICl}$ in the embryonic fibroblasts in vitro. $\mathrm{E}_{2}$ and/or $\mathrm{ER} \alpha$ agonist PPT did not have any effect on the p-AKT protein levels in the embryonic fibroblast cultures, whereas $E_{2}$ and PPT significantly up-regulated the phosphorylation of AKT in whole bladder culture. These data suggest that the gene expression changes observed in primary fibroblast culture exposed to $E_{2}$ stimulation in vitro are mediated mainly by estrogen receptors, and most predominantly via $\mathrm{ER} \alpha$, without the activation of $\mathrm{p}-\mathrm{AKT}$. This was further confirmed by immunohistological finding of p-AKT-positive cells detected only in the urothelia of $\mathrm{AROM}+/ 6 \mathrm{~J}$, but not in the spindle-like fibroblasts.

Taken together, our data showed that increased local estrogen action through Cyp19a1 overexpression, promoted murine urothelial cell proliferation in vivo and in vitro (see Supplementary Figure S4 at http://ajp.amjpathol.org). This proliferative effect was elicited via $\mathrm{ER} \alpha$-mediated sig- naling. The activated estrogen/ER $\alpha$ pathway inhibited PTEN expression, which in turn activated the PI3K/AKT pathway, finally resulting in urothelial cell proliferation in $B O O$. Local $E_{2} / E R \alpha$ promoted intradetrusor fibroblast activation without the activation of p-AKT and further enhanced fibroblast hyperproliferation and impaired the accumulation of type III collagen within the detrusor. These findings suggest that excess estrogen action on the bladder may functionas the etiological signal leading to $\mathrm{BOO}$ through modification of the smooth muscle layer and urothelium. AROM+/6J mice may serve as an ideal experimental model to study the molecular mechanisms involved in the development of non-neurogenic BOO, and drugs such as CYP19A1 inhibitors, selective estrogen and androgen receptor modulators, or PI3K inhibitors for the treatment of $\mathrm{BOO}$.

\section{Acknowledgment}

We thank Evan Simpson for providing the aromatase cDNA and for valuable advice for the project.

\section{References}

1. Hald T: Urodynamics in benign prostatic hyperplasia: a survey. Prostate Suppl 1989, 2:69-77

2. Andersson KE: Storage and voiding symptoms: pathophysiologic aspects. Urology 2003, 62(5 Suppl 2):3-10

3. Andersson KE: LUTS treatment: future treatment options. Neurourol Urodyn 2007, 26(6 Suppl):934-947

4. Parsons JK: Modifiable risk factors for benign prostatic hyperplasia and lower urinary tract symptoms: new approaches to old problems. J Urol 2007, 178:395-401

5. Irwin DE, Milsom I, Kopp Z, Abrams P, Artibani W, Herschorn S: Prevalence, severity, and symptom bother of lower urinary tract symptoms among men in the EPIC study: impact of overactive bladder. Eur Urol 2009, 56:14-20

6. Irwin DE, Milsom I, Hunskaar S, Reilly K, Kopp Z, Herschorn S, Coyne K, Kelleher C, Hampel C, Artibani W, Abrams P: Population-based survey of urinary incontinence, overactive bladder, and other lower urinary tract symptoms in five countries: results of the EPIC study. Eur Urol 2006, 50:1306-1314; discussion 1314-1305

7. Glasser DB, Carson C 3rd, Kang JH, Laumann EO: Prevalence of storage and voiding symptoms among men aged 40 years and older in a US population-based study: results from the Male Attitudes Regarding Sexual Health study. Int J Clin Pract 2007, 61:1294-1300

8. Vallancien G, Pariente P: Treatment of lower urinary tract symptoms suggestive of benign prostatic obstruction in real life practice in France. Prostate Cancer Prostatic Dis 2001, 4:124-131

9. Kay L, Stigsby B, Brasso K, Mortensen SO, Munkgaard S: Lowe urinary tract symptoms-a population survey using the Danish Prostatic Symptom Score (DAN-PSS) questionnaire. Scand J Urol Nephrol 1999, 33:94-99

10. Koskimäki J, Hakama M, Huhtala H, Tammela TL: Prevalence of lower urinary tract symptoms in Finnish men: a population-based study. Br J Urol 1998, 81:364-369

11. Chute CG, Panser LA, Girman CJ, Oesterling JE, Guess HA, Jacobsen SJ, Lieber MM: The prevalence of prostatism: a population-based survey of urinary symptoms. J Urol 1993, 150:85-89

12. Krieg M, Weisser $H$, Tunn S: Androgen- und Estrogenstoffwechsel in der menschlichen benignen Prostatahyperplasie (BPH). [Androgen and estrogen metabolism in human benign prostatic hyperplasia (BPH)]. German. Verh Dtsch Ges Pathol 1993, 77:19-24

13. Schweikert HU, Tunn UW: Effects of the aromatase inhibitor testolactone on human benign prostatic hyperplasia. Steroids 1987, 50:191200

14. Schatzl G, Brössner C, Schmid S, Kugler W, Roehrich M, Treu T, Szalay A, Djavan B, Schmidbauer CP, Söregi S, Madersbacher S; The 
Prostate Study Group of the Austrian Society of Urology: Endocrine status in elderly men with lower urinary tract symptoms: correlation of age, hormonal status, and lower urinary tract function. Urology 2000 55:397-402

15. Behre HM, Bohmeyer J, Nieschlag E: Prostate volume in testosterone-treated and untreated hypogonadal men in comparison to agematched normal controls. Clin Endocrinol (Oxf) 1994, 40:341-349

16. Lahdes-Vasama TT, Koskimäki JE, Streng TK, Fisch RD, Nilson EA, Santti RS, Tammela TL: Urodynamic findings in men operated on for an undescended testicle. BJU Int 2003, 92:972-976

17. Chun AL, Wein AJ, Harkaway R, Levin RM: Comparison of urinary bladder function in sexually mature and immature male and female rats. J Urol 1990, 143:1267-1271

18. Kaufman JM, Vermeulen A: Declining gonadal function in elderly men. Baillieres Clin Endocrinol Metab 1997, 11:289-309

19. Morley JE, Patrick P, Perry HM 3rd: Evaluation of assays available to measure free testosterone. Metabolism 2002, 51:554-559

20. Partin AW, Oesterling JE, Epstein JI, Horton R, Walsh PC: Influence of age and endocrine factors on the volume of benign prostatic hyperplasia. J Urol 1991, 145:405-409

21. Ekman P: The prostate as an endocrine organ: androgens and estrogens. Prostate Suppl 2000, 10:14-18

22. Kimm S, Mazar C, Salkini MW, Comiter CV: Solifenacin succinate prevents urodynamic and detrusor changes associated with bladder outlet obstruction-a mouse model (abstract). J Urol 2009, 181(4 Suppl):693

23. Lehtimäki J, Mäkel̈ AS, Viljamaa J, Yagi A, Paranko J, Santti R: Neonatal estrogenization of the male mouse results in urethral dysfunction. J Urol 1996, 156:2098-2103

24. Afar DE, Vivanco I, Hubert RS, Kuo J, Chen E, Saffran DC, Raitano $A B$, Jakobovits $A$ : Catalytic cleavage of the androgen-regulated TMPRSS2 protease results in its secretion by prostate and prostate cancer epithelia. Cancer Res 2001, 61:1686-1692

25. Bianco JJ, Handelsman DJ, Pedersen JS, Risbridger GP: Direct response of the murine prostate gland and seminal vesicles to estradiol. Endocrinology 2002, 143:4922-4933

26. Lemack GE, Zimmern PE, Vazquez D, Connell JD, Lin VK: Altered response to partial bladder outlet obstruction in mice lacking inducible nitric oxide synthase. J Urol 2000, 163:1981-1987

27. Bernoulli J, Yatkin E, Konkol Y, Talvitie EM, Santti R, Streng T: Prostatic inflammation and obstructive voiding in the adult Noble rat: impact of the testosterone to estradiol ratio in serum. Prostate 2008 , 68:1296-1306

28. Spearow JL, Doemeny P, Sera R, Leffler R, Barkley M: Genetic variation in susceptibility to endocrine disruption by estrogen in mice. Science 1999, 285:1259-1261

29. Li X, Nokkala E, Yan W, Streng T, Saarinen N, Wärri A, Huhtaniemi I, Santti R, Mäkel̈ AS, Poutanen M: Altered structure and function of reproductive organs in transgenic male mice overexpressing human aromatase. Endocrinology 2001, 142:2435-2442

30. Li X, Wärri A, Mäkel̈ AS, Ahonen T, Streng T, Santti R, Poutanen M: Mammary gland development in transgenic male mice expressing human P450 aromatase. Endocrinology 2002, 143:4074-4083

31. Li X, Strauss L, Mäkelä S, Streng T, Huhtaniemi I, Santti R, Poutanen M: Multiple structural and functional abnormalities in the p450 aromatase expressing transgenic male mice are ameliorated by a p450 aromatase inhibitor. Am J Pathol 2004, 164:1039-1048

32. Kaufman $\mathrm{MH}$, Robertson EJ, Handyside AH, Evans MJ: Establishment of pluripotential cell lines from haploid mouse embryos. J Embryol Exp Morphol 1983, 73:249-261

33. Groutz A, Blaivas JG: Non-neurogenic female voiding dysfunction. Curr Opin Urol 2002, 12:311-316

34. Huhtaniemi I, Nikula H, Rannikko S: Treatment of prostatic cancer with a gonadotropin-releasing hormone agonist analog: acute and long term effects on endocrine functions of testis tissue. J Clin Endocrinol Metab 1985, 61:698-704

35. Li X, Strauss L, Kaatrasalo A, Mayerhofer A, Huhtaniemi I, Santti R, Mäkel̈ A S, Poutanen M: Transgenic mice expressing p450 aromatase as a model for male infertility associated with chronic inflammation in the testis. Endocrinology 2006, 147:1271-1277

36. Revankar CM, Cimino DF, Sklar LA, Arterburn JB, Prossnitz ER: A transmembrane intracellular estrogen receptor mediates rapid cell signaling. Science 2005, 307:1625-1630

37. Monson FC, Sun L, Wein AJ, Levin RM: Hyperplasia in the rabbit bladder urothelium following partial outlet obstruction. Autoradiographic evidence. Mol Cell Biochem 1995, 152:167-173

38. Kasper S, Sheppard PC, Yan Y, Pettigrew N, Borowsky AD, Prins GS, Dodd JG, Duckworth ML, Matusik RJ: Development, progression, and androgen-dependence of prostate tumors in probasin-large $\mathrm{T}$ antigen transgenic mice: a model for prostate cancer [Corrected and republished from Lab Invest 1998;78(3):319-333]. Lab Invest 1998, 78(6):i-xv

39. Teng J, Wang ZY, Jarrard DF, Bjorling DE: Roles of estrogen receptor alpha and beta in modulating urothelial cell proliferation. Endocr Relat Cancer 2008, 15:351-364

40. Uvelius B, Persson L, Mattiasson A: Smooth muscle cell hypertrophy and hyperplasia in the rat detrusor after short-time infravesical outflow obstruction. J Urol 1984, 131:173-176

41. Oelke M, Höfner K, Wiese B, Grünewald V, Jonas U: Increase in detrusor wall thickness indicates bladder outlet obstruction (BOO) in men. World J Urol 2002, 19:443-452

42. Mäkinen S, Mäkelä S, Weihua Z, Warner M, Rosenlund B, Salmi S, Hovatta O, Gustafsson JA: Localization of oestrogen receptors alpha and beta in human testis. Mol Hum Reprod 2001, 7:497-503

43. Bodker A, Balslev E, Juul BR, Stimpel $H$, Meyhoff $H H$, Hedlund $H$, Hedlund P, Iversen HG, Andersson KE: Estrogen receptors in the human male bladder, prostatic urethra, and prostate. An immunohistochemical and biochemical study. Scand J Urol Nephrol 1995, 29 : 161-165

44. Schröder A, Pandita RK, Hedlund P, Warner M, Gustafsson JA, Andersson KE: Estrogen receptor subtypes and afferent signaling in the bladder. J Urol 2003, 170:1013-1016

45. Renner O, Blanco-Aparicio C, Carnero A: Genetic modelling of the PTEN/AKT pathway in cancer research. Clin Transl Oncol 2008, 10:618-627

46. Trimboli AJ, Cantemir-Stone CZ, Li F, Wallace JA, Merchant A, Creasap N, Thompson JC, Caserta E, Wang H, Chong JL, Naidu S, Wei G, Sharma SM, Stephens JA, Fernandez SA, Gurcan MN, Weinstein MB, Barsky SH, Yee L, Rosol TJ, Stromberg PC, Robinson ML, Pepin F, Hallett M, Park M, Ostrowski MC, Leone G: Pten in stromal fibroblasts suppresses mammary epithelial tumours. Nature 2009, 461:1084-1091

47. Blanco A, Grana B, Fachal L, Santamarina M, Cameselle-Teijeiro J, Ruiz-Ponte C, Carracedo A, Vega A: Beyond BRCA1 and BRCA2 wild-type breast and/or ovarian cancer families: germline mutations in TP53 and PTEN. Clin Genet 2010, 77:193-196

48. Marino M, Acconcia F, Trentalance A: Biphasic estradiol-induced AKT phosphorylation is modulated by PTEN via MAP kinase in HepG2 cells. Mol Biol Cell 2003, 14:2583-2591

49. Klotz DM, Hewitt SC, Ciana P, Raviscioni M, Lindzey JK, Foley J, Maggi A, DiAugustine RP, Korach KS: Requirement of estrogen receptor-alpha in insulin-like growth factor-1 (IGF-1)-induced uterine responses and in vivo evidence for IGF-1/estrogen receptor crosstalk. J Biol Chem 2002, 277:8531-8537

50. Stevenson K, Kucich U, Whitbeck C, Levin RM, Howard PS: Functional changes in bladder tissue from type III collagen-deficient mice. Mol Cell Biochem 2006, 283:107-114

51. Deveaud CM, Macarak EJ, Kucich U, Ewalt DH, Abrams WR, Howard PS: Molecular analysis of collagens in bladder fibrosis. J Urol 1998, 160:1518-1527

52. Kaplan EP, Richier JC, Howard PS, Ewalt DH, Lin VK: Type III collagen messenger RNA is modulated in non-compliant human bladder tissue. J Urol 1997, 157:2366-2369

53. Chavalmane AK, Comeglio P, Morelli A, Filippi S, Fibbi B, Vignozzi L, Sarchielli E, Marchetta M, Failli P, Sandner P, Saad F, Gacci M, Vannelli GB, Maggi M: Sex steroid receptors in male human bladder: expression and biological function. J Sex Med 2010, 8:2698-2713 